\title{
Identifying the drivers of liking for texture attributes of Vietnamese sausage
}

\author{
Pham Huu Thinh*, Nguyen Vu Van Thuy, Nguyen Thi Hien, Nguyen Hoang Dzung
}

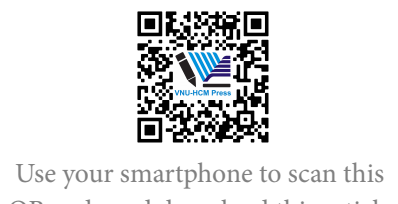

QR code and download this article
Food Technology, Department of Chemical Engineering, Ho Chi Minh City University of Technology, Ho Chi Minh City, Vietnam

\section{Correspondence}

Pham Huu Thinh, Food Technology, Department of Chemical Engineering, Ho Chi Minh City University of Technology, Ho Chi Minh City, Vietnam

Email: 1870069@hcmut.edu.vn

History

- Received: 17-3-2021

- Accepted: 09-5-2021

- Published: 19-5-2021

DOI : 10.32508/stdjet.v4i2.819

\section{Check for updates}

\section{Copyright}

(c) VNU-HCM Press. This is an openaccess article distributed under the terms of the Creative Commons Attribution 4.0 International license.

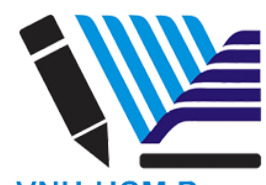

VNU-HCM Press

\begin{abstract}
Vietnamese sausage (chalua), a pork processing food with a characteristic chewy and crunchy texture, are widely consumed in Vietnam. However, there are not many established researchs on hedonic and sensory attributes for this product, especially about the texture attributes. The goal of this study was to investigate the consumer's preference as well as identify the drivers of liking for texture of Vietnamese sausage. Eight samples were prepared with various ratio of lean meat, lard and starch to cover a wide range of different texture of Vietnamese sausage. Sixty eight consumers then evaluated these eight samples, rating texture liking on nine-point scale and answering a check-all-thatapply (CATA) question, which consisted of 16 different texture attributes of Vietnamese sausage. The consumers were also asked to check all the approriate attributes to describe their ideal products. The ANOVA and post -hoc test showed samples which had recipes with $20-25 \%$ lard ratio and $70 \%$ meat ratio had a significant higher liking scores, while the samples which had recipe with $90 \%$ meat ratio had the lowest liking scores. The Cochran's Q test showed that 12 attributes had different choice frequency between samples, suggesting the texture of Vietnamese sausage is complex and diverse. The CA results showed all the samples without stach were associated with large air holes, while samples which high meat ratio (80\%) were associated with hardness. The ideal Vietnamese sausage product was associated with fattiness, juiciness, springiness and brittleness. Finally, the results of penalty analysis showed that chewiness, firmness and springiness had positive impacts on the liking score for Vietnamese sausage products, while attributes that exhibit heterogeneity, such as large air hole and grainy, significantly reduced the liking score of the product. This suggested the importance of mechanical texture attributes and homogenity on the consumer's preference of the Vietnamese sausage.
\end{abstract}

Key words: Vietnamese sausage, texture, driver of liking, CATA

\section{INTRODUCTION}

In Vietnam, pork and pork processing products are widely consumed. According to the statistic by the Ministry of Agriculture, pork production was $2,143,992$ tons/year in 2019 . The average pork consumption of Vietnamese people had also reached $35 \mathrm{~kg} /$ people/year. Among pork processing products in Vietnam, the Vietnamese sausage (cha lua) is one of the most popular food. This traditional food has a characteristic chewy and crunchy texture, with rich aroma and flavor of pork and spice. Vietnamese sausage is generally produced by grinding and mixing lean pork and lard ${ }^{1}$. The grinding and mixing helps creating the meat emulsion, which plays an important role in the formation of product shape and texture. This meat emulsion creates a dense and hard to break texture for the Vietnamese sausage. Starch is also added to the grinding process. The interactions between starch and proteins (mainly hydrogen bonds) give the product a characteristic springiness. In addition to the main ingredients (lean meat, lard and starch), spices and condiments, such as salt, fish sauce, sugar, garlic, pepper, are added in the blending step to enhance the flavor of the product. A number of additives such as polyphosphate salts, vitamin C, flavoring agents, ... are also added to enhance the texture of the Vietnamese sausage product.

For food products, texture is one of the major sensory properties that drives consumer acceptance ${ }^{2}$. Texture is often not a focus point in sensory evaluation like flavour, however, if the consumers' expectations of texture are not met, awareness of textural defects is accentuated, and texture becomes the main point for criticism and rejection of the food. Texture is even more important for sausage products, since firm, elastic texture with good bite is characteristics for this type of food ${ }^{3}$.

Many researchs has been conducted about the texture of sausage product in the world. M.P. Ruiz PerezCacho and H.Gallan-Soldevilla et al (2005) developed a list of 15 lexicons to describe the texture and flavour of Spain dry-cured sausage salchichón ${ }^{4}$. A.M. Her- 
rero and J.A. Ordonez et al (2007) investigated the relationship between breaking strength and texture profile analysis of dry fermented sausages ${ }^{5}$. F. Coloretti and L. Grazia et al (2015) refined a procedure for texture evaluation of Salama da sugo, an Italian fermented sausage ${ }^{6}$. In contrast, in spite of its popularity, there has not been many researchs about the texture of Vietnamese sausage. This study is therefore conducted to determine the drivers of liking for texture of Vietnamese sausage, contributing to creating directions for development of this product.

\section{MATERIAL - METHODS}

\section{Material}

Eight Vietnamese sausage samples were produced with different ingredient ratio according to the recipes in Table 1. The meat and lard were first minced separately, then grinded and mixed together at $10^{\circ} \mathrm{C}$ for 3 minutes, using a bowl cutter, to create the meat emulsion. Starch then added to the mixture at $1.5 \mathrm{~min}$ utes. Other ingredients (spices and additives) were added to the mixture at the 2-minutes mark. The other ingredients, which were fixed between different recipes, included $10.8 \mathrm{~g}$ fish sauce, $11.4 \mathrm{~g}$ sugar, $5.1 \mathrm{~g}$ monosodium glutamate, $2.5 \mathrm{~g}$ polyphosphate, $7.6 \mathrm{~g}$ salt and $100 \mathrm{~g}$ ice per $1 \mathrm{~kg}$ mixture of lean pork, lard and starch.

\begin{tabular}{llll}
\multicolumn{3}{l}{$\begin{array}{l}\text { Table 1: Ingredient ratio for Vietnamese sausage } \\
\text { production }\end{array}$} & \multicolumn{3}{l}{ Lard } & Starch \\
\hline Sample & Meat & $30 \%$ & $0 \%$ \\
A1 & $70 \%$ & $10 \%$ & $0 \%$ \\
A2 & $90 \%$ & $20 \%$ & $10 \%$ \\
B1 & $70 \%$ & $10 \%$ & $10 \%$ \\
B2 & $80 \%$ & $20 \%$ & $0 \%$ \\
A3 & $80 \%$ & $25 \%$ & $5 \%$ \\
C1 & $70 \%$ & $10 \%$ & $5 \%$ \\
C2 & $85 \%$ & $15 \%$ & $10 \%$ \\
B3 & $75 \%$ & & \\
\hline
\end{tabular}

For sensory evaluation, the Vietnamese sausages were cut into slice of approximately $1 \mathrm{~cm}$ thickness and divided into 8 equally fan-shaped sections. Each section was presented to one test participant, and the time between preparation and testing was less than $30 \mathrm{~min}$ utes.

\section{Sensory evaluation}

Sixty eight consumers, ranging from 18 to 26 years old and consisting of undergraduate and graduated stu- dents at University of Technology, Ho Chi Minh City, were randomly recruited to participate in the consumer test. All participants consumed Vietnamese sausage at least once a week and had interests in this study. Testing was conducted in standard sensory booths, with temperatures at $25-27^{0} \mathrm{C}$. Samples were labelled with 3-digit code and were presented to the panelist randomly and balancely in a monadic sequence using the Latin William square. Mineral water was provided to the panelist so they could clean their palate between sample trials.

The participants were first asked to complete a checkall-that-apply (CATA) question with 16 texture attributes (Table 2), developed using a trained panel. The participants then scored their texture liking using a 9-point hedonic scale. After evaluating 8 samples, the participants described their ideal texture of Vietnamese sausage using the same 16 texture attributes.

\section{Table 2: Check-all-that-apply (CATA) attribute list}

\begin{tabular}{ll}
\hline Roughness & Chewiness \\
Porosity & Juiciness \\
Large air hole & Fattiness \\
Adhesiveness & Fibrous \\
Hardness & Grainy \\
Springiness & Brittleness \\
Firmness & Clinginess \\
Mealy & Glassy \\
\hline
\end{tabular}

\section{Data analysis}

Liking scores were analysed with two-factor ANOVA (consumers and samples) with samples as fixed source of variance and consumers as a random effect. If the ANOVA showed differences in preference between samples, Fisher's least significant difference post hoc test was used for pairwise comparison between samples'texture liking score.

The frequency of occurrence of each attribute per sample was summarized in a contingency table. This contingency table was then analyzed by Cochran's Q test to identify atrributes which consumer considered important for evaluating the texture of Vietnamese sausage. For visualization of the CATA results, CA (Correnspondence Analysis) with $\chi 2$-distance was often used $^{7-9}$. The CA analysis represented the distribution of samples and the ideal product on a two 
dimension space, as well as the relationship between samples and attributes from the CATA question.

To classify attributes as positive (must-have) or negative (must-not-have), penalty analysis was applied. G.Ares et al (2014) suggested looking at incongruence between elicitations of attributes for the ideal and selected real products (samples), where incongruence is defined as an attribute applying to the ideal or the real product only, but not both ${ }^{10}$. Liking ratings were then averaged across consumers with incongruent and congruent elicitations, respectively. The difference between the liking rating for congruent and incongruent elicitations indicated how much liking changed when the product did not match the ideal product. This change in liking could indicate which attributes had positive or negative impacts on the overall texture liking of consumers.

All of the data analysis was done using XLSTAT 2020.5 and $\mathrm{R} 4.0 .3^{11,12}$.

\section{RESULTS}

\section{Texture liking scores}

ANOVA test showed significant difference in texture liking score between Vietnamese sausage samples $(p$ value $<0.0001)$. Figure 1 showed that sample $\mathrm{C} 1$ had the highest average texture liking score (6.79), followed by sample B1 (6.19). Both of C1 and B1 samples had a recipe with low meat ratio (70\%) and high lard ratio (25\% for $\mathrm{C} 1$ and $20 \%$ for $\mathrm{B} 1$ ). On the contrary, the A2 sample, which had very high meat ratio (90\%) and low lard ratio (10\%), had the lowest average texture liking score (5.38).

\section{Texture attributes}

The Cochran's Q test statistics for all attributes (Table 3) used in the CATA question showed that twelve terms were different in frequency of selection for different samples at the significance level $\alpha=0.05$ (because grainy had a marginal $p$-value $=0.054$, this attribute was also considered to be different). The attributes which did not show differences in frequency were adhesiveness, brittleness, clinginess and glassy. This result suggested the complexity and diversity of the texture of Vietnamese sausage.

Figure 2 showed the result of the CA analysis. The total differences of the first two CA dimension, F1 and F2, was high (82.25\%), so no further dimension was considered. CA result showed that the Vietnamese sausage samples were distributed into four distinct groups. With the exception of sample $\mathrm{C} 1$, all remaining samples were relatively far away from the ideal sample, suggesting that these samples had many attributes that negatively affecting their liking score.

\section{Identification of drivers of liking}

Figure 3 showed the average liking score drop corresponding to the percentage selected for product but not for ideal (P(No)I(Yes)). Percentage was calculated by the ratio between the frequency of selecting an attribute corresponding to $\mathrm{P}(\mathrm{No}) \mathrm{I}(\mathrm{Yes})$ and the frequency of selecting that attribute for the ideal sample I(Yes). The vertical axis represents the average liking score decrease and the horizontal axis represents the percentage choice. It can be seen that the attributes that had both high coordinates of the vertical and horizontal axes are must-have attributes (because the high ratio of choosing this attribute for the ideal but not for products resulted in a reduced liking score). Firmness, brittleness, chewiness, springiness, juiciness and fattiness were must-have attributes for Vietnamese sausage samples.

Figure 4 showed the average liking score drop relative to the percentage of choosing an attribute for a product without selecting that attribute for the ideal $\mathrm{P}(\mathrm{Yes}) \mathrm{I}(\mathrm{No})$. It can be seen that the attributes with high negative mean drop and high percentage are must-not-have attributes. Large air hole, porosity, roughness, grainy and mealy were must-not-have attributes. Figure 4 can also help identifying nice-tohave attributes. Attributes which had a positive mean drop and a high percentage selected are nice-to-have attributes (because when the attributes were detected in a product but not for the ideal, it leaded to an increase in liking score, or in other words, consumers were excited about these attributes). None of the attributes were nice-to-have. Glassy, adhesiveness, fibrous and clinginess were not classified as either must-have or must-not-have, so these attributes were not influenced the texture liking of consumers. The final classification are summarized in Table 4.

\section{DISCUSSION}

The liking score analysis showed that texture had a significant impact on the consumer preference of the Vietnamese sausage, suggesting the consumers were aware of the difference in texture of the Vietnamese sausage. A surprising result was that the Vietnamese sausage sample $\mathrm{C} 1$, which had recipe with low meat and high lard ratio, had the highest liking score. Previous researchs showed that consumers tended to like sausage products with high content of meat, since the meat content has a positive relationship with hardness and chewiness. The protein in meat played a major role in the firmness of sausage products, while increasing the fat content significantly reduced the mechanical textural characteristics of the 


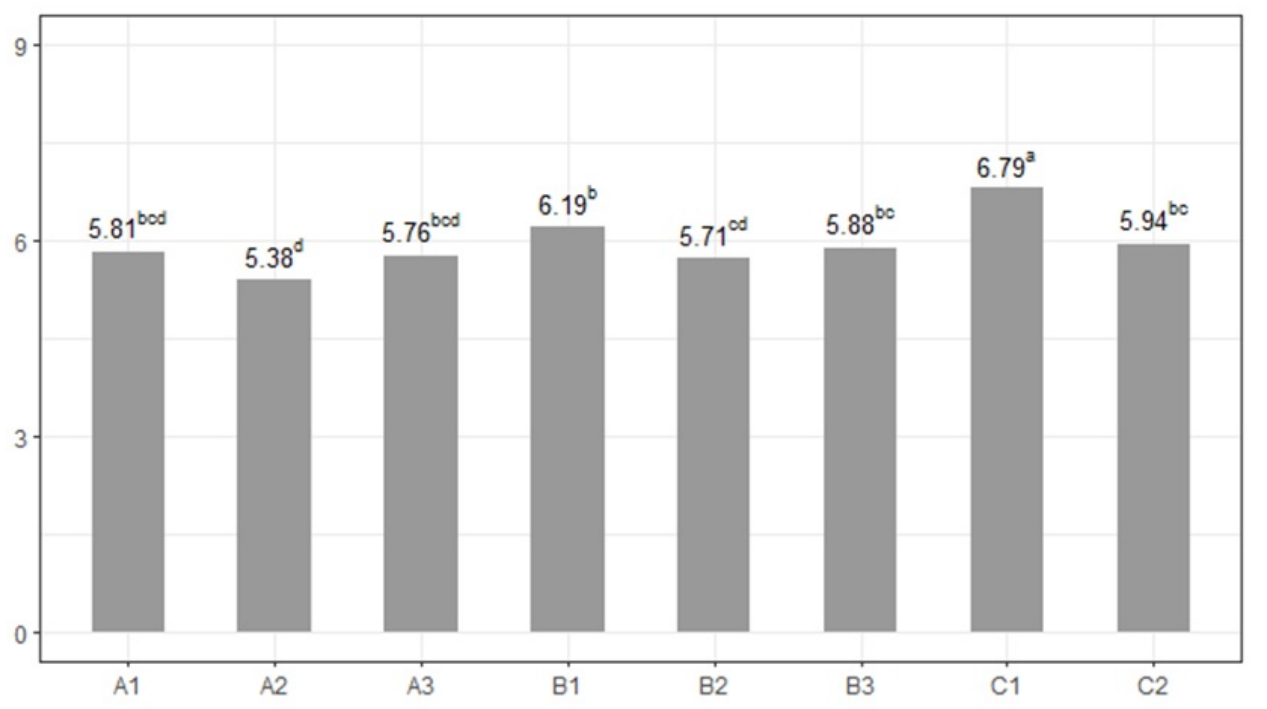

Figure 1: Mean score of texture liking for Vietnamese sausage samples.

Table 3: Cochran's $Q$ test for check-all-that-apply (CATA) attributes

\begin{tabular}{llll}
\hline Attributes & p-values & Attributes & p-values \\
Roughness & $<0.0001$ & Chewiness & $<0.0001$ \\
Porosity & $<0.0001$ & Juiciness & $<0.0001$ \\
Large air holes & $<0.0001$ & Fattiness & $<0.0001$ \\
Adhesiveness & 0.861 & Fibrous & $<0.0001$ \\
Hardness & $<0.0001$ & Grainy & 0.054 \\
Springiness & $<0.0001$ & Brittleness & 0.587 \\
Firmness & $<0.0001$ & Clinginess & 0.404 \\
Mealy & $<0.0001$ & Glassy & 0.672 \\
\hline
\end{tabular}

sausages like hardness and cohesiveness ${ }^{13}$. This implied consumers now prefered softer and less chewy Vietnamese sausage products.

For texture attributes, the CA analysis showed interesting links between ingredient ratio and texture attributes (Figure 2). Sample A1, A2 and A3 lied in the positive direction of the F1 axis, and were associated with fibrous, porosity and large air holes. Starch was not added to these three sample, suggesting that the lack of starch caused air holes to appear in the Vietnamese sausage. Sample B1, B3 and C2, located near the origin of coordinates and associated with clinginess, chewiness and adhesiveness. Sample B2, which had very high lean meat ratio $(80 \%)$ and low lard ratio (10\%), located on the negative direction of the F2 axis and were associated with hardness. This showed that high meat ratio and low lard ratio tended to make the texture of Vietnamese sausage firm and hard to break, which is in accordance with the results of A.Olivares and J.L.Navarro et al (2010) on slow fermented pork sausage ${ }^{14}$. Finally, the ideal sample and $\mathrm{C} 1$ located at the positive direction of F2, and were associated with fattiness, juiciness and springiness. These terms, which also closely located near the ideal product, were suggested as the drivers of liking for Vietnamese sausage.

The analysis of drivers of liking showed that all the mechanical (except hardness) and mouthfeel texture attributes had positive impact on liking score, suggesting the importance of these attributes to Vietnamese sausage products. Both the mechanical and mouthfeel texture attributes manifest as the reaction of food to stress and characterize how the food behaves during manipulation and mastication. There- 


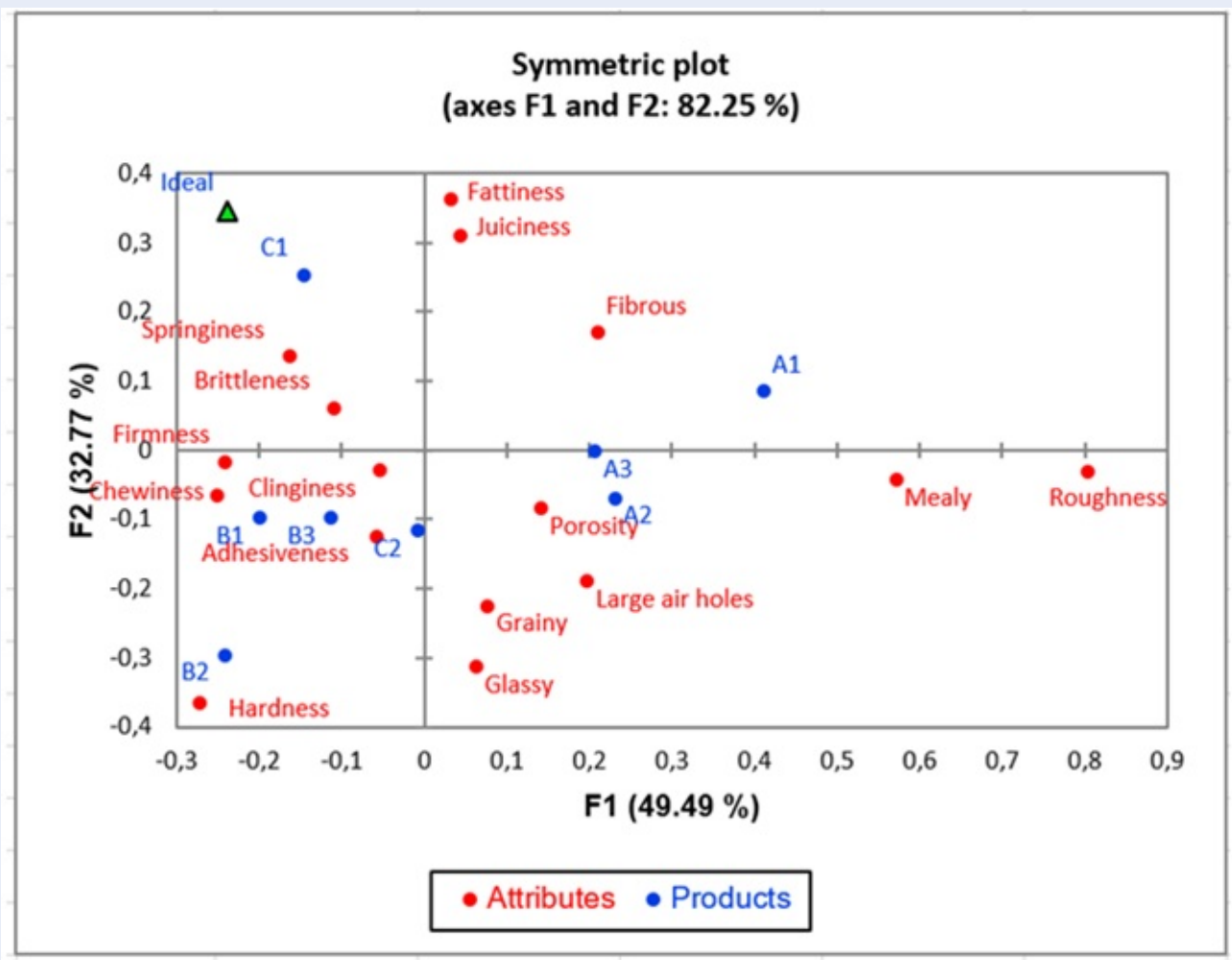

Figure 2: Representation of samples and CATA attributes in F1 \& F2 dimension of CA

Table 4: Classification of attributes by penalty analysis

\begin{tabular}{ll}
\hline Groups & Attributes \\
Must-have attibutes & Firmness \\
& Brittleness \\
& Chewiness \\
& Springiness \\
& Juiciness \\
& Fattiness \\
Nice-to-have attributes & \\
Does-not-influence attributes & Adhesiveness \\
& Fibrous \\
& Clinginess \\
& Glassy \\
& Large air hole \\
Must-not-have attributes & Porosity \\
& Roughness \\
& Hardness \\
& Grainy \\
& Mealy \\
\hline
\end{tabular}

fore, these texture attributes are often the focus when consumers evaluate texture, thus contribute greatly to the liking of food products. In contrast, appearance attributes (large air holes, porosity, roughness), despite being the first attributes that consumers perceive, usually do not have a high impact on the liking score of sausage products ${ }^{15}$. However, for Vietnamese sausage, the appearance attributes (large air holes, porosity, roughness) had significantly negative impact on the liking score, suggesting the Vietnamese consumer paid much attention to the outside look.

\section{CONCLUSION}

The results showed that consumers paid much attention to the mechanical and the mouthfeel texture. These texture attributes increased the liking score for Vietnamese sausage products when they appeared. In contrast, texture attributes that exhibited heterogeneity such as large air holes, porosity and grainy significantly reduced the liking score of the product. In summary, the results accentuated the importance of firmness and good bite texture for Vietnamese sausages. However, further research are needed to investigate the link between texture evaluated by consumers and 


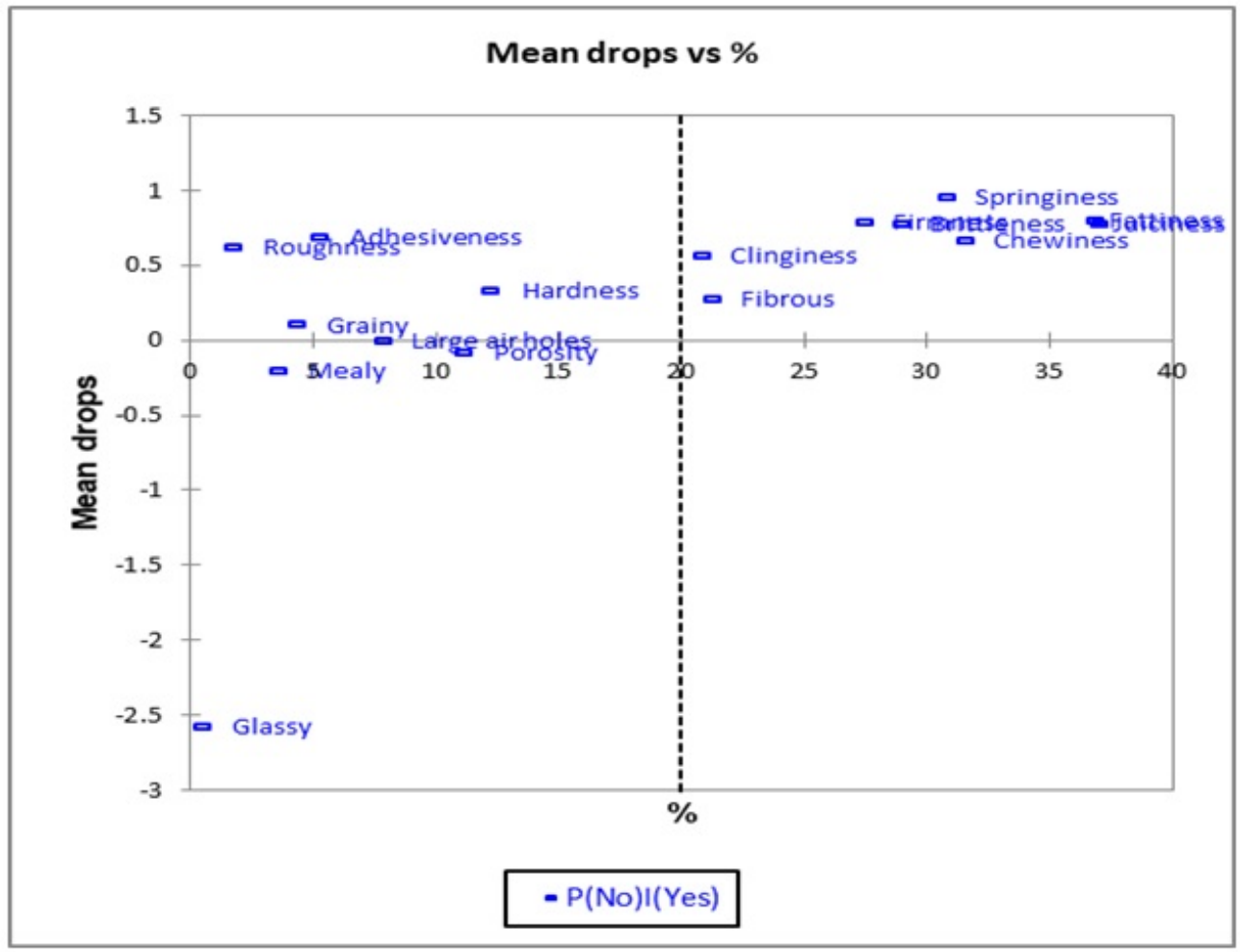

Figure 3: Mean drops of liking score of texture attributes corresponding to the percentage selected $\mathrm{P}(\mathrm{No})$ )(Yes)

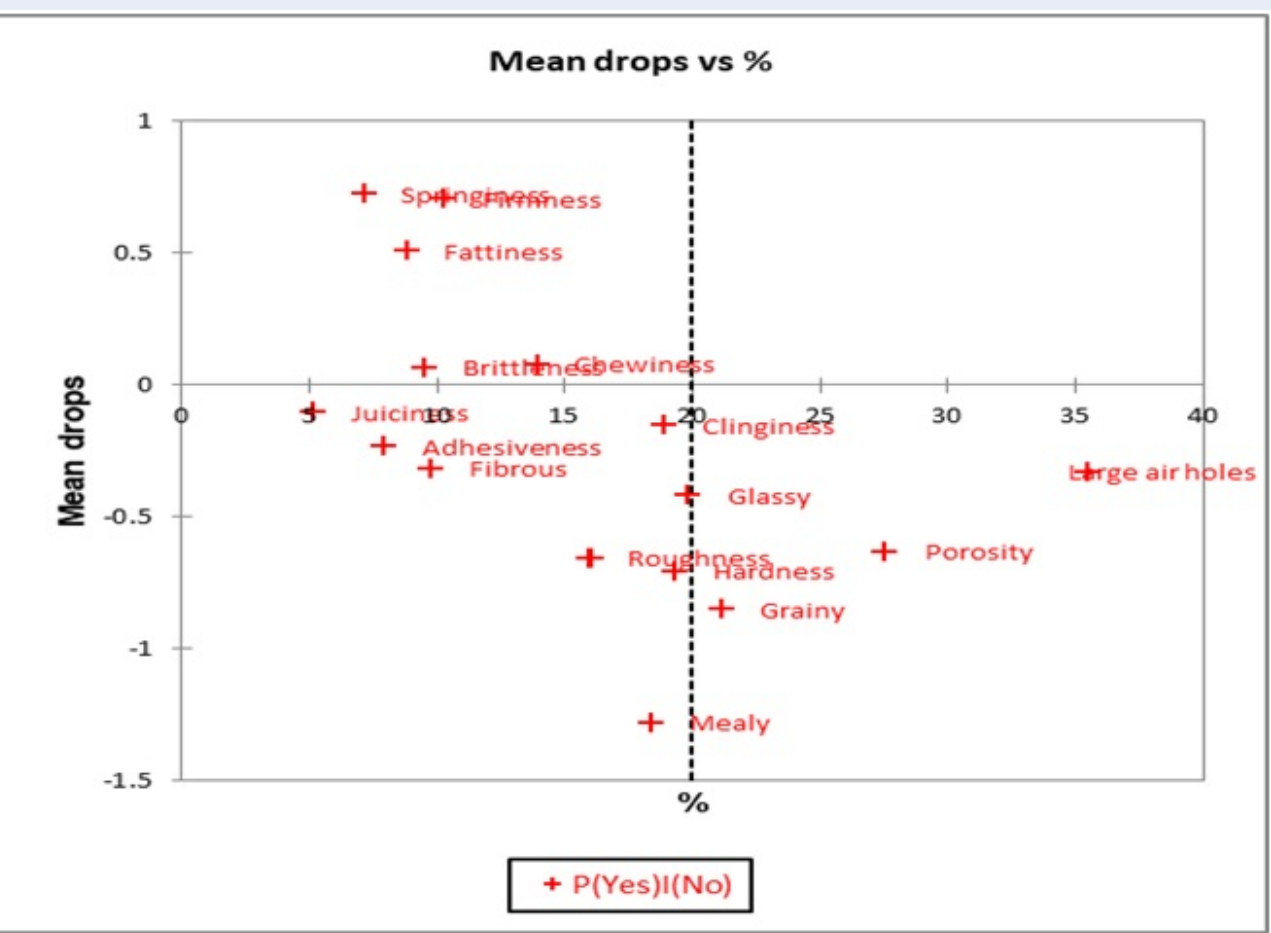

Figure 4: Mean drops of liking score of texture attributes corresponding to the percentage selected $\mathrm{P}(\mathrm{Yes})$ ( (No) 
the structure (molecular, microscopic and macroscopic) of the Vietnamese sausages, to clearly establish the direction for Vietnamese sausage product development.

\section{ACKNOWLEDGEMENT}

This research is funded by Vietnam National University of Ho Chi Minh City University of Techonology - VNU-HCM under grant number To-KTHH-201911.

\section{LIST OF ABBREVIATIONS}

ANOVA: Analysis of variances

CA: Correspondence analysis

CATA: check-all-that-apply

\section{COMPETING INTERESTS}

The authors declare that they have no competing interests

\section{AUTHORS' CONTRIBUTION}

Nguyen Hoang Dung, Nguyen Thi Hien designed the ideas for the study and planned the consumer test. Pham Huu Thinh, Nguyen Vu Van Thuy conducted the consumer test, analyzed the data and wrote the manuscript.

All authors provided critical feedback, discussion, and helped finishing the manuscript.

\section{REFERENCES}

1. Quyên TTT, Cúc HTK, Tiên LTT. Công nghệ sản xuất giò chả. Bộ Nông nghiệp và phát triển nông thôn;p. 1-131.

2. Szczesniak AS. Texture is a sensory property. Food Qual Prefer. 2002;13:215-25;Available from: https://doi.org/10.1016/ S0950-3293(01)00039-8.

3. Bozkurt H, Bayram M. Colour and textural attributes of sucuk during ripening. Meat Sci. 2006;73(2):344-50;PMID: 22062307. Available from: https://doi.org/10.1016/j.meatsci.2006.01.001.
4. Pérez-Cacho MPR, Galán-Soldevilla H, Crespo FL, Recio GM. Determination of the sensory attributes of a Spanish drycured sausage. Meat Sci. 2005;71(4):620-33;PMID: 22061207. Available from: https://doi.org/10.1016/j.meatsci.2005.05.005.

5. Herrero AM, Ordóñez JA, de Avila R, Herranz B, de la Hoz L Cambero Ml. Breaking strength of dry fermented sausages and their correlation with texture profile analysis (TPA) and physico-chemical characteristics. Meat Sci. 2007;77(3):3318;PMID: 22061785. Available from: https://doi.org/10.1016/j. meatsci.2007.03.022.

6. Coloretti F, Grazia L, Gardini F, Lanciotti R, Montanari C, Tabanelli $G$, et al. A procedure for the sensory evaluation of Salama da sugo, a typical fermented sausage produced in the Emilia Romagna Region, Italy. J Sci Food Agric 2015;95(5):1047-54;PMID: 24954381. Available from: https: //doi.org/10.1002/jsfa.6793.

7. Jorge E da C, Mendes ACG, Auriema BE, Cazedey HP, Fontes PR, Ramos A de LS, et al. Application of a check-all-that-apply question for evaluating and characterizing meat products. Meat Sci. 2015;100:124-33;PMID: 25460115. Available from: https://doi.org/10.1016/j.meatsci.2014.10.002.

8. Ares G, Dauber C, Fernández E, Giménez A, Varela P. Penalty analysis based on CATA questions to identify drivers of liking and directions for product reformulation. Food Qual Prefer. 2014;32:65-76;Available from: https://doi.org/10.1016/j. foodqual.2013.05.014.

9. Julien DJBL and MR. Rapid Sensory Profiling Techniques and Related Methods. Woodhead Publishing Limited. 2015;555.

10. Varela P, Ares G. Novel Techniques in Sensory Characterization Profiling and Consumer. CRC Press. 2014;p. 408. Available from: https://doi.org/10.1201/b16853.

11. Addinsoft. XLSTAT statistical and data analysis solution. Long Island, NY, USA. 2021;Available from: https://www.xlstat.com.

12. $\mathrm{R}$ Core Team. R: A language and environment for statistical computing. R Foundation for Statistical Computing, Vienna, Austria. 2020;Available from: https://www.R-project.org/.

13. Pietrasik Z. Effect of content of protein, fat and modi ${ }^{\circ}$ ed starch on binding textural characteristics, and colour of comminuted scalded sausages. Meat Sci. 1999;51:17-25;Available from: https://doi.org/10.1016/S0309-1740(98)00068-0.

14. Olivares A, Navarro JL, Salvador A, Flores M. Sensory acceptability of slow fermented sausages based on fat content and ripening time. Meat Sci. 2010;86(2):251-7;PMID: 20510528. Available from: https://doi.org/10.1016/j.meatsci.2010.04.005.

15. Carrapiso Al, Martín-Cabello L, Torrado-Serrano C, Martín L. Sensory Characteristics and Consumer Preference of Smoked Dry-Cured Iberian Salchichon. Int J Food Prop. 2015;18(9):1964-72;Available from: https://doi.org/10.1080/ 10942912.2014 .942781$. 


\title{
Xác định các tính chất cấu trúc có ảnh hưởng quan trọng đến thị hiếu của sản phẩm chả lụa
}

\author{
Phạm Hữu Thịnh ${ }^{*}$, Nguyễn Vũ Vân Thủy, Nguyễn Thị Hiền, Nguyễn Hoàng Dũng
}

Bộ môn Công nghệ Thực phẩm, Khoa Kỹ thuật Hóa học, Đại học Bách khoa, ĐHQG TP.HCM, Việt Nam

Liên hệ

Phạm Hữu Thịnh, Bộ môn Công nghệ Thực phẩm, Khoa Kỹ thuật Hóa học, Đại học Bách khoa, ĐHQG TP.HCM, Việt Nam

Email: 1870069@hcmut.edu.vn

Lịch sử

- Ngày nhận: 17-3-2021

- Ngày chấp nhận: 09-5-2021

- Ngày đăng: 19-5-2021

DOI : 10.32508/stdjet.v4i2.819

\section{Check for updates}

\section{Bản quyền}

๑ ĐHQG Tp.HCM. Đây là bài báo công bố mở được phát hành theo các điều khoản của the Creative Commons Attribution 4.0 International license.

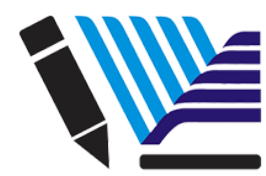

VNU-HCM Press

\section{TÓM TẮT}

Chả lụa, một sản phẩm chế biến từ thịt heo với cấu trúc dai giòn đặc trưng, được tiêu dùng rộng rãi ơ Việt Nam. Tuy nhiên, chưa có nhiêu nghiên cứu về thị hiếu và tính chất cảm quan cho sản phẩm này, nhất là nghiên cứu về nhóm tính chất cấu trúc. Mục tiêu của nghiên cứu này là tìm hiểu về sự ưa thích của người tiêu dùng và xác định các tính chất cấu trúc có ảnh hưởng quan trọng đến thị hiếu của sản phẩm chả lụa. Tám mẫu chả lụa được chuẩn bị với các tỉ lệ thành phần thịt nạc, mỡ và tinh bột khác nhau nhằm bao quát được sự đa dạng về cấu trúc của sản phẩm chả lụa. Sáu mươi tám người tiêu dùng tiến hành đánh giá tám mẫu chả lụa này, đưa ra điểm ưa thích trên thang 9 điểm và trả lời câu hỏi lựa chọn từ phù hợp (check-alll-that-apply, CATA), danh sách từ bao gồm 16 tính chất cấu trúc khác nhau của sản phẩm chả lụa. Người tiêu dùng sau đó lựa chọn các từ phù hợp để mô tả mẫu sản phẩm chả lụa lý tưởng của họ. Kết quả phân tích ANOVA và kiểm định hậu nghiệm cho thấy các mẫu chả lụa có công thức với lượng mỡ 20-25\% và lượng thịt 70\% có điểm ưa thích cao hơn hẳn các mẫu còn lại, trong khi mẫu chả lua với lượng thịt $90 \%$ có điểm ưa thích thấp nhất. Kết quả kiểm định Cochran's Q test cho thấy có 12 tính chất có sự khác biệt về tần số lựa chọn giữa các mẫu, cho thấy cấu trúc của sản phẩm chả lụa rất phức tạp và đa dạng. Kết quả phân tích CA cho thấy các mẫu chả lụa không bổ sung tinh bột có quan hệ với tính chất lỗ khí lớn, trong khi các mẫu chả lụa với lượng thịt cao (80\%) được lại có quan hệ tốt với tính chất cứng. Mẫu chả lụa lý tưởng có quan hệ tốt với các tính chất béo, mọng nước, đàn hồi và sần sật. Cuối cùng, kết quả phân tích thiệt hại cho thấy dẻo, chắc và đàn hồi là các tính chất tích cực, trong khi các tính chất thể hiện sự không đồng nhất, như lỗ khí to trên bề mặt hay cảm giác bột khi nhai, làm giảm đáng kể điểm ưa thích của sản phẩm chả lụa. Các kết quả trên cho thấy sự ảnh hưởng quan trọng của các tính chất cấu trúc cơ lý và sự đông nhất đến sự ưa thích của người tiêu dùng đối với sản phẩm chả lụa.

Từ khoá: chả lụa, cấu trúc, thị hiếu, CATA 